\title{
Articles
}

\section{TESTS OF FUNCTIONAL FORMS, CURRENCY SUBSTITUTION, AND CAPITAL MOBILITY OF CZECH MONEY DEMAND FUNCTION}

\author{
Yu Hsing *
}

\begin{abstract}
:
The demand for real M2 in the Czech Republic is positively influenced by real output and negatively associated with the deposit rate, the koruna/euro exchange rate, and the euro interest rate. The coefficient of real output for the demand for real M1 is insignificant. Hence, depreciation of the koruna or a higher euro interest rate would help raise Czech real output. The Box-Cox transformation test shows that the log-linear form for real M1 and M2 demand cannot be rejected at the $5 \%$ level while the linear form for real M1 and M2 demand can be rejected at the $5 \%$ level. The CUSUM and CUSUMSQ tests show that parameters in the demand for both real M1 and M2 demand are stable. In comparison, real M2 is a better monetary aggregate.
\end{abstract}

Keywords: Box-Cox transformation, currency substitution, wealth effect, capital mobility effect, cost of borrowing effect, stability tests

JEL Classification: E41, O52

\section{Introduction}

The study of Czech economy is relevant due to its recent entrance into the EU in 2004. Examining the demand for money will allow for better understanding of its causes and effects on the country's economic activities. This paper has the following focuses. First, the Box-Cox transformation (Box and Cox, 1964; Greene, 2003, pp. 173-175; Hsing, 2006) is applied to determine which functional form, such as the

*) Charles Blackwell Endowed Professor in Economics, College of Business, Southeastern Louisiana University, Hammond, Louisiana 70402, USA (yhsing@ selu.edu) 
conventional log-linear form is appropriate. Second, because the signs for the nominal exchange rate and the foreign interest rate in the money demand function are unclear, empirical estimation is required to determine whether a change in the exchange rate or the foreign interest rate would shift LM rightward or leftward. Third, in the Mundell-Fleming model, the sign of the nominal exchange rate would determine whether LM is vertical and whether fiscal policy would affect the real output or the exchange rate.

Several seminal works or review articles (Tobin, 1958; Chow, 1966; Goldfeld, 1973, 1976; Judd and Scadding, 1982; Gordon, 1984; Laidler, 1990; Goldfeld and Sichel, 1990) have contributed substantially to the understanding of the demand for money. Small and Porter (1989), Hetzel and Mehra (1989), Hafer and Jansen (1991), Mehra (1993, 1997), Duca (2000), Carlson, Hoffman, Keen and Rasche (2000), and others examined the behavior and stability of M2 for the US. For example, Mehra (1997) indicated that the demand for M2 shifted leftward during the early 1990s and that the behavior of M2 has remained relatively stable since 1994 and may be useful for the analysis of monetary policy. Duca (2000) showed that the decline in M2 and the rise in M2 velocity in the early 1990s were matched by the increase in bond mutual funds. He suggested that the demand for M2 can be modeled better if the market for bond mutual funds is also taken into consideration. Carlson, Hoffman, Keen and Rasche (2000) maintained that after a permanent increase in the M2 velocity during 1990-1994, there has been a stable relationship for M2M and MZM and that people switched certain portion of assets from CDs to mutual funds on a permanent basis.

Taylor (1991) and Taylor and Phylaktis (1993) indicated that the major variable in determining the demand for money for high inflation countries was inflation expectations and that monetary policy led to the maximization of the inflation tax. Bahmani-Oskooee and Chomsisengphet (2002) revealed that the UK and Switzerland had unstable money demand functions while the other nine OECD countries had stable money demand functions. Bahmani-Oskooee and Rehman (2005) showed that for selected Asian countries, even if M1 or M2 was cointegrated with other variables, the money demand function was not stable.

Klacek and Šmídková (1995) examined the demand for different monetary aggregates for the Czech Republic. They chose private consumption as a scale variable due to the poor performance of GDP. The inflation rate was significant for real narrow money, while the foreign interest rate was significant for real broad money. Van Aarle and Budina (1996) showed that there was evidence of currency substitution for Hungary, Poland, Bulgaria, and Romania. Cuthbertson and Bredin (2001) indicated that although currency substitution happened just once and would not repeat again, the foreign interest rate should be examined in monitoring changes in the demand for money. Komárek and Melecký (2001) showed that the demand for real M1 had a positive relationship with industrial output, the price index and the own rate and a negative relationship with the interest rate on time deposits and that the demand for real M2 had a positive relationship with the price index, industrial output, the CZK/USD exchange rate, and the CZK/DEM exchange rate and a negative relationship with the interest rate on credit, the lagged CZK/USD exchange rate, the US Treasury bill rate, and the German Treasury bill rate. The inflation rate was found insignificant in most models. Komárek and Melecký (2003) also found evi- 
dence of capital mobility and currency substitution in money demand for the Czech Republic.

\section{The Model}

Extending previous studies, the demand for real money balances in the Czech Republic can be written as

$$
M_{d}=L\left(Y, R, \varepsilon, R^{f}\right), L_{Y}>0, L_{R}<0, L_{\varepsilon}>\text { or }<0, L_{R^{f}}>\text { or }<0
$$

where $M_{d}, Y, R, \varepsilon$ and $R^{f}$ stand for the demand for real money balances, real GDP, the deposit rate, the nominal exchange rate (korunas per euro dollar), and the foreign interest rate.

The signs of the partial derivative of the demand for money with respect to the nominal exchange rate and the foreign interest rate in equation (1) are crucial because they may influence the equilibrium real output differently. Based on the goods and money market equilibrium, the impact of exchange rate depreciation on the equilibrium real output is given by

$$
\partial \bar{Y} / \partial \varepsilon=\left(-H_{\varepsilon} L_{R}+H_{R} L_{\varepsilon}\right) /|J|>\text { or }<0 \text { if } L_{\varepsilon}>0 \text { and }>0 \text { if } L_{\varepsilon}<0 .
$$

where $H_{\varepsilon}$ is the partial derivative of aggregate spending with respect to the nominal exchange rate, $H_{R}$ is the partial derivative of aggregate spending with respect to the domestic interest rate, and $|J|$ is the Jacobian with a positive value. Currency depreciation would cause the equilibrium real output to rise if $L_{\varepsilon}$ is negative. If the demand for money responds to a higher foreign interest rate negatively, an increased foreign interest rate would shift LM rightward and raise real output:

$$
\partial \bar{Y} / \partial R^{f}=H_{R} L_{R^{f}} /|J|>0 \text { if } L_{R^{f}}<0 \text { and }<0 \text { if } L_{R^{f}}>0
$$

where $L_{R^{f}}$ is the partial derivative of money demand with respect to the foreign interest rate. The extended Box-Cox model (Box and Cox, 1963; Greene, 2003; Hsing, 2006) is employed to transform all the variables with positive values as follows:

$$
\begin{aligned}
& M_{d}^{(\lambda)}=\left(M_{d}^{\lambda}-1\right) / \lambda \\
& X^{(\lambda)}=\left(X^{\lambda}-1\right) / \lambda
\end{aligned}
$$

where $\mathrm{X}$ is any of the right-hand-side variables and $\lambda$ is the transformation parameter. It can be shown that when $\lambda$ approaches zero, equation (1) reduces to a double$\log$ form, and when $\lambda=1$, equation (1) becomes a linear form. The test statistic has a $\chi^{2}$ distribution with one degree of freedom and is given by

$$
J(\lambda)=2[L(\hat{\lambda})-L(\lambda=0 \text { or } 1)] \sim \chi_{(1)}^{2}
$$

The elasticity of real money demand with respect to any explanatory variable $\mathrm{X}$ at the means is given by

$$
E_{X}=\beta\left(\bar{X} / \bar{M}_{d}\right)^{\lambda}
$$


where $E_{X}$ is the elasticity of $M_{d}$ with respect to any variable $\mathrm{X}$ and $\beta$ is the estimated coefficient for any variable $\mathrm{X}$.

\section{Empirical Results}

The data source came from the International Financial Statistics published by the International Monetary Fund except that the exchange rate was collected from the Czech National Bank. Real M1 or M2 are equal to nominal M1 or M2 divided by the CPI and measured in billions. Real GDP is measured in billions at the 1995 price. The deposit rate is selected to represent the domestic interest rate. The exchange rate is expressed as korunas per euro dollar. Hence, an increase in the exchange rate means depreciation of the koruna. The euro government bond yield is chosen to represent the foreign interest rate. The sample runs from 1999.Q1 to 2005.Q3. Data for the koruna/euro exchange before 1999.Q1 are not available.

The ADF unit root test is performed. The critical values are $-3.57,-2.92$, and -2.60 at the $1 \%, 5 \%$ and $10 \%$ levels. All the variables in levels have unit roots, and all the variables in first difference are stationary. The ADF cointegration test for real M1 demand shows that the test statistic of 3.59 is greater than the critical value of 3.17 at the $5 \%$ level. The ADF cointegration test for real M2 demand reveals that the test statistic of 3.55 is greater than the critical value of 3.17 at the $5 \%$ level. Hence, real M1 or M2 are cointegrated with the four explanatory variables.

The functional form is tested. The critical value with a $\chi^{2}$ distribution and 1 degree of freedom is 3.841 and 6.635 at the $5 \%$ and $1 \%$ levels, respectively. In Table 1, for real M1 demand, the value of $L(\hat{\lambda})$ is -125.104 with an estimated $\lambda$ of -0.414 . The value of $L(\lambda=0)$ for the double-log form is -126.940 . The test statistic is 3.672. Hence, the log-linear form cannot be rejected at the 5\% level. On the other hand, the value of $L(\lambda=1)$ for the linear form is -138.543. Comparing the test statistic of 26.878 with the $\chi_{(1)}^{2}$ value of 3.841 at the $5 \%$ level, the linear form can be rejected. As shown in Table 2, for real M2 demand, the value of $L(\hat{\lambda})$ is -128.251 with an estimated $\lambda$ of 0.251 . The value of $L(\lambda=0)$ for the double-log form is -128.493 . Hence, the log-linear form cannot be rejected at the 5\% level. On the other hand, the value of $L(\lambda=1)$ for the linear form is -130.206 . Comparing the test statistic of 3.910 with the $\chi_{(1)}^{2}$ value of 3.841 at the $5 \%$ level, the linear form can be rejected. Because of the above outcomes, the log-linear regressions are used.

Table 1 presents the estimated regression and related statistics for the demand for real M1. The paper does not employ the first-difference form because the results would become obscure due to the loss of important information (Greene, 2003). As shown, $98.2 \%$ of the variation in the demand for real M1 can be explained by the four right-hand side variables. All the coefficients are significant at the $1 \%$ or $5 \%$ level except that the coefficient for real output in real M1 has an unexpected sign and is insignificant. The demand for real M1 is negatively influenced by the deposit rate, the koruna/euro dollar exchange rate, and the euro government bond yield. In Table 2, 97.3\% of variation in the demand real M2 can be explained by the four explanatory variables. All the coefficients are significant at the different level. The demand for real M2 is positively influenced by real output and negatively associated with the deposit rate, the koruna/euro dollar exchange rate, and the euro govern- 
ment bond yield. In comparison, it is clear that real M1 demand is much more sensitive to the deposit rate, the exchange rate, and the euro interest rate than real M2 demand. The negative sign of the exchange rate shows that depreciation of the koruna leads to a decrease in the demand for money and implies that the substitution effect is greater than the wealth effect (Arango and Nadiri, 1981; McKinnon, 1982; Bahmani-Oskooee and Techaratanachai, 2001; Bahmani-Oskooee and Ng, 2002). The negative sign of the euro interest rate suggests that the capital mobility effect is greater than the cost of borrowing effect (Marquez, 1987; Bahmani-Oskooee and $\mathrm{Ng}, 2002$ ). According to estimated regressions, because M1 or M2 demand responds negatively to a change in the CZK/euro exchange rate, LM is not vertical and is upward sloping. Hence, in the Mundell-Fleming model, expansionary fiscal policy would raise real output and the exchange rate if LM is steeper than IS.

Based on the CUSUM and CUSUMSQ tests, Figure 1 shows that the money demand function for the Czech Republic is relatively stable as most of the cumulative sum of the recursive residuals or squared residuals fall within the 5\% critical lines. Real M1 demand has a mean absolute percent error of 3.433 and a Theil inequality coefficient of 0.020 while real M2 demand has a mean absolute percent error of 1.501 and a Theil inequality coefficient of 0.009 . In comparison, it appears that real M2 demand is a better monetary aggregate.

Several different versions are considered. If the koruna/USD exchange rate and the U.S. Treasury bill rate replace the koruna/euro dollar exchange rate and the euro government bond yield, the coefficients are more significant mainly due to a larger sample size, and other results are similar. When real household consumption is used as a scale variable for the demand for real M1, its coefficient is negative and insignificant. If the expected inflation rate measured as the average inflation rate of past four quarters is included in the regression, the coefficient is positive and insignificant for real M1 demand, and the coefficient is positive and significant for real M2 demand. These suggest that multicollinearity may cause the changes in the sign and significance tests.

\section{Conclusions}

This study has examined the demand for real M1 and M2 in the Czech Republic. The focus is on two explanatory variables, namely, the nominal exchange rate and the foreign interest rate. The Box-Cox transformation is applied to find that the loglinear form cannot be rejected while the linear form can be rejected. The regression was estimated by the Newey-West method, which generates consistent estimates when the forms of heteroskedasticity and autorcorrelation are unknown. The results show that the demand for real M2 has a positive relationship with real output and a negative relationship with the domestic deposit rate, currency depreciation, and the euro interest rate. Similar results are found for the demand for real M1 except that the coefficient for real output is insignificant probably due to the multicollinearity problem that normally exists in time series data. These findings are consistent with the findings of Van Aarle and Budina (1996) and Komárek and Melecký (2003, 2004) that there was currency substitution and are partially in contrast with Cuthbertson and Bredin (2001) and Komárek and Melecký (2004) that currency substitution was a one-time event and that the exchange rates had positive or negative 
impacts on the demand for real M2. Different results suggest that the demand for money in each of the countries may be characterised by unique relationships. The CUSUM and CUSUMSQ tests indicate stability in the money demand function as the cumulative sum of recursive residuals or squared residuals fall within the 5\% critical values. The mean absolute percent error and the Theil inequality coefficient suggest that real M2 demand is a better monetary aggregate. These empirical results would be helpful in analysing the impact of a change in the exchange rate or the foreign interest rate on real output in the Czech Republic.

There may be areas for future research. Other model specifications and estimation methods may be considered. The expected inflation rate may be constructed in different manners. If the sample size is large enough, short-term variation in the demand for real M1 and M2 may be examined by the error-correction model.

Table 1

\section{The Demand for Real M1 for the Czech Republic}

\begin{tabular}{|c|c|c|c|c|}
\hline \multicolumn{5}{|c|}{$\begin{array}{l}\text { Dependent Variable: } \log (\text { Real M1) } \\
\text { Method: Least Squares } \\
\text { Sample (adjusted): } 1999 \text { Q1 2005Q3 } \\
\text { Included observations: } 27 \text { after adjustments } \\
\text { Newey-West HAC Standard Errors \& Covariance (lag truncation=2) }\end{array}$} \\
\hline Variable & Coefficient & Std. Error & t-Statistic & Prob. \\
\hline $\begin{array}{l}\text { C } \\
\text { Log(Real Output }) \\
\text { Log(Deposit Rate }) \\
\text { Log(CZK/euro Exc.Rate }) \\
\text { Log(Euro Bond Yield })\end{array}$ & $\begin{array}{r}10.70450 \\
-0.217724 \\
-0.511679 \\
-0.624135 \\
-0.219405\end{array}$ & $\begin{array}{l}2.097499 \\
0.265400 \\
0.040479 \\
0.243171 \\
0.092323\end{array}$ & $\begin{array}{r}5.103458 \\
-0.820362 \\
-12.64047 \\
-2.566650 \\
-2.376494\end{array}$ & $\begin{array}{l}0.0000 \\
0.4208 \\
0.0000 \\
0.0176 \\
0.0266\end{array}$ \\
\hline $\begin{array}{l}\text { R-squared } \\
\text { Adjusted R-squared } \\
\text { S.E. of regression } \\
\text { Sum squared resid. } \\
\text { Log likelihood } \\
\text { Durbin-Watson stat. }\end{array}$ & $\begin{array}{l}0.982450 \\
0.979259 \\
0.044814 \\
0.044183 \\
48.29463 \\
1.019537\end{array}$ & \multicolumn{2}{|c|}{$\begin{array}{l}\text { Mean dependent var. } \\
\text { S.D. dependent var. } \\
\text { Akaike info criterion } \\
\text { Schwarz criterion } \\
\text { F-statistic } \\
\text { Prob(F-statistic) }\end{array}$} & $\begin{array}{r}6.490161 \\
0.311169 \\
-3.207009 \\
-2.967040 \\
307.8823 \\
0.000000\end{array}$ \\
\hline
\end{tabular}

Notes:

$$
\begin{aligned}
& L(\hat{\lambda})=-125.104 \text { where } \hat{\lambda}=-0.414, \\
& L(\lambda=0)=-126.940, \text { and } \\
& L(\lambda=1)=-138.543 \text {. }
\end{aligned}
$$


Table 2

The Demand for Real M2 for the Czech Republic

\begin{tabular}{|c|c|c|c|c|}
\hline \multicolumn{5}{|c|}{$\begin{array}{l}\text { Dependent Variable: } \log (\text { Real M2) } \\
\text { Method: Least Squares } \\
\text { Sample (adjusted): 1999Q1 2005Q3 } \\
\text { Included observations: } 27 \text { after adjustments } \\
\text { Newey-West HAC Standard Errors \& Covariance (lag truncation=2) }\end{array}$} \\
\hline Variable & Coefficient & Std. Error & t-Statistic & Prob. \\
\hline $\begin{array}{l}\text { C } \\
\log (\text { Real Output }) \\
\log (\text { Deposit Rate }) \\
\log (\text { CZK/euro Exc. Rate }) \\
\log (\text { Euro Bond Yield })\end{array}$ & $\begin{array}{r}7.350066 \\
0.187977 \\
-0.150516 \\
-0.268347 \\
-0.061217\end{array}$ & $\begin{array}{l}0.832088 \\
0.102880 \\
0.016261 \\
0.100862 \\
0.031063\end{array}$ & $\begin{array}{r}8.833283 \\
1.827152 \\
-9.256422 \\
-2.660551 \\
-1.970751\end{array}$ & $\begin{array}{l}0.0000 \\
0.0813 \\
0.0000 \\
0.0143 \\
0.0615\end{array}$ \\
\hline $\begin{array}{l}\text { R-squared } \\
\text { Adjusted R-squared } \\
\text { S.E. of regression } \\
\text { Sum squared resid. } \\
\text { Log likelihood } \\
\text { Durbin-Watson stat. }\end{array}$ & $\begin{array}{l}0.972733 \\
0.967775 \\
0.020334 \\
0.009096 \\
69.63117 \\
1.271879\end{array}$ & \multicolumn{2}{|c|}{$\begin{array}{l}\text { Mean dependent var. } \\
\text { S.D. dependent var. } \\
\text { Akaike info criterion } \\
\text { Schwarz criterion } \\
\text { F-statistic } \\
\text { Prob(F-statistic) }\end{array}$} & $\begin{array}{r}7.337940 \\
0.113272 \\
-4.787494 \\
-4.547524 \\
196.2089 \\
0.000000\end{array}$ \\
\hline
\end{tabular}

Notes:

$L(\hat{\lambda})=-128.251$ where $\hat{\lambda}=0.251$,

$L(\lambda=0)=-128.493$, and

$L(\lambda=1)=-130.206$.

Figure 1

\section{CUSUM and CUSUMSQ tests}

\section{CUSUM Test for real M1}

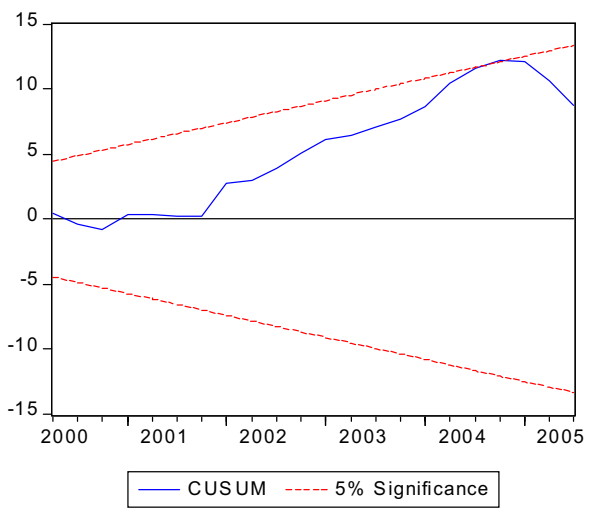

\section{CUSUMSQ Test for Real M1}

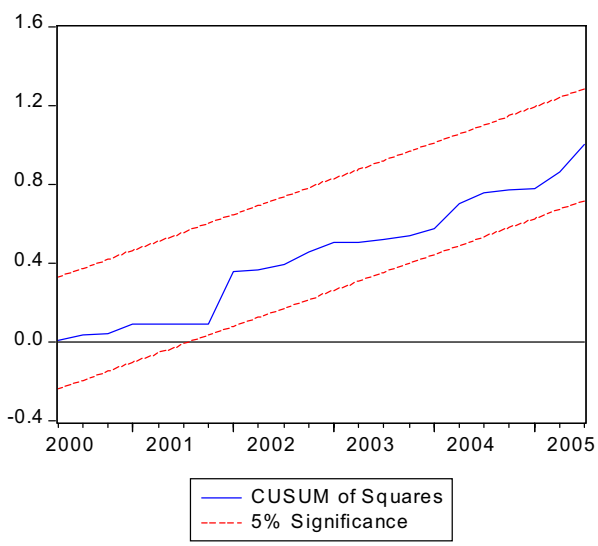




\section{CUSUM Test for Real M2}

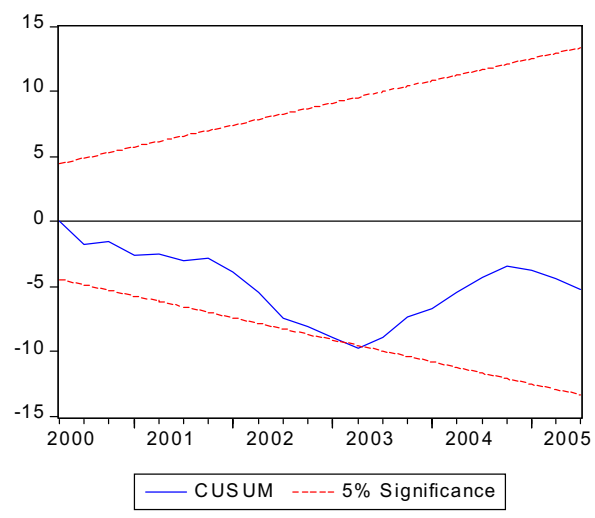

\section{CUSUMSQ Test for Real M2}

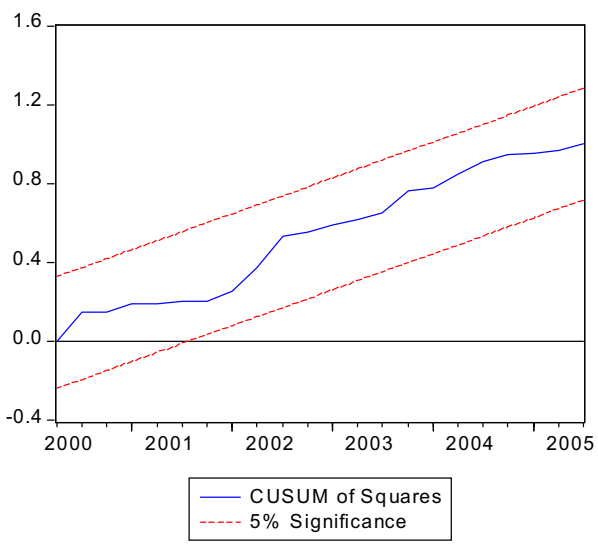

\section{References}

Arango, S., Nadiri, M.I. (1981), "Demand for Money in Open Economies." Journal of Monetary Economics, 7(1), pp. 69-83.

Bahmani-Oskooee, M., Techaratanachai, A. (2001), "Currency Substitution in Thailand." Journal of Policy Modeling, 23(2), pp. 141-1.45.

Bahmani-Oskooee, M., Chomsisengphet, S. (2002), "Stability of M2 Money Demand Function in Industrial Countries." Applied Economics, 34(16), pp. 2075-2083.

Bahmani-Oskooee, M., Ng, R.C.W. (2002), "Long-Run Demand for Money in Hong Kong: An Application of the ARDL Model." International Journal of Business and Economics, 1, pp. 147155.

Bahmani-Oskooee, M., Rehman, H. (2005), "Stability of the Money Demand Function in Asian Developing Countries." Applied Economics, 37(7), pp. 773-792.

Box, G.E.P., Cox, D.R. (1964), "An Analysis of Transformation." Journal of Royal Statistical Society, 26(2), pp. 211-252.

Carlson, J.B., Hoffman, D.L., Keen, B.D., Rasche, R.H. (2000), "Results of a Study of the Stability of Cointegrating Relations Comprised of Broad Monetary Aggregate." Journal of Monetary Economics, 46(2), pp. 345-383.

Chow, G.C. (1966), "On the Long-Run and Short-Run Demand for Money." Journal of Political Economy, 74(2), pp. 111-131.

Cuthbertson, K., Bredin, D. (2001), "Money Demand in the Czech Republic since Transition." Journal of Policy Reform, 4(4), pp. 271-290.

Duca, J.V. (2000), "Financial Technology Shocks and the Case of the Missing M2." Journal of Money, Credit, and Banking, 32(4), Part 1, pp. 820-39.

Fair, R.C. (1987), "International Evidence on the Demand for Money." Review of Economics and Statistics, 69(3), pp. 473-480.

Goldfeld, S.M. (1973), "The Demand for Money Revisited." Brookings Papers on Economic Activity, 3, pp. 577-638.

Goldfeld, S.M. (1976), "The Case of the Missing Money." Brookings Papers on Economic Activity, 3, pp. 683-730.

Goldfeld, S., Sichel D. (1990), "The Demand for Money," in Handbook of Monetary Economics, by B. M. Friedman and F. H. Hahn, Eds., Volume 1, North-Holland, Amsterdam. 
Gordon, R.J. (1984), “The Short-Run Demand for Money: A Reconsideration.” Journal of Money, Credit, and Banking, 16(4), Part 1, pp. 403-434.

Greene, W.H. (2003), Econometric Analysis, fifth edition. Upper Saddle River, NJ: Prentice Hall.

Hafer, R.W., Jansen, D.W. (1991), "The Demand for Money in the United States: Evidence from Cointegration Tests." Journal of Money, Credit, and Banking, 23(2), pp. 155-168.

Hetzel, R.L., Mehra Y.P. (1989), "The Behavior of Money Demand in the 1980s." Journal of Money, Credit, and Banking, 21(4), pp. 455-463.

Hsing, Y. (2006) "The Roles of the Exchange Rate and the Foreign Interest Rate in Estonian Money Demand Function and Policy Implications." Applied Financial Economics Letters, forthcoming.

Judd, J.L., Scadding, J.L. (1982), "The Search for a Stable Money Demand Function: A Survey of the Post-1973 Literature." Journal of Economic Literature, 20(3), pp. 993-1023.

Klacek, J., Šmídková, K. (1995), "The Demand for Money Function: The Case of the Czech Economy." Czech National Bank Working Paper Series 41, Praha.

Komárek, L., Melecký, M. (2003), "Currency Substitution in a Transitional Economy with an Application to the Czech Republic." Eastern European Economics, 41(4), pp. 72-99.

Komárek, L., Melecký, M. (2001), "Demand for Money in the Transition Economy: The Case of the Czech Republic 1993-2001." University of Warwick, Department of Economics, Warwick Economics Research Paper Series (TWERPS).

Laidler, D. (1990), The Demand for Money: Theories, Evidence. and Problems, $3^{\text {rd }}$ edition. New York: HarperCollins.

Marquez, J. (1987), "Money Demand in Open Economies: A Currency Substitution Model for Venezuela." Journal of International Money and Finance, 6(2), pp. 167-178.

McKinnon, R. (1982), "Currency Substitution and Instability in the World Dollar Standard." American Economic Review, 72(3), 320-333.

Mehra, Y.P. (1993), "The Stability of the M2 Demand Function: Evidence from an Error-Correction Model." Journal of Money, Credit, and Banking, 25(3), pp. 455-460.

Mehra, Y.P. (1997), "A Review of the Recent Behavior of M2 Demand." Federal Reserve Bank of Richmond Economic Quarterly, 83(3), pp. 27-43.

Phylaktis, K., Taylor, M.P. (1993), "Money Demand, the Cagan Model and the Inflation Tax: Some Latin American Evidence." Review of Economics and Statistics, 75(1), pp. 32-37.

Romer, D. (2006), Advanced Macroeconomics, third edition. New York: McGraw-Hill.

Small, D.H., Porter, R.D. (1989), "Understanding the Behavior of M2 and V2." Federal Reserve Bulletin, 75(4), pp. 244-254.

Taylor, M.P. (1991), "The Hyperinflation Model of Money Demand Revisited." Journal of Money, Credit \& Banking, Part 1, 23(3), pp. 327-351.

Tobin, J. (1958), "Liquidity Preference as Behavior toward Risk." Review of Economic Studies, 25(2), pp. 65-86.

Van Aarle, B., Budina, N. (1996), "Currency Substitution and Seignorage in Eastern Europe." Journal of Policy Reform, 1(3), pp. 279-298. 